\title{
EU, Conflict Transformation and Civil Society: Promoting Peace from the Bottom Up?
}

\author{
Nathalie Tocci ${ }^{1}$ \\ ${ }^{1}$ Istituto Affari Internazionali (IAI), Rome, Italy \\ Correspondence: Nathalie Tocci, Deputy Director, Istituto Affari Internazionali (IAI), Via Angelo Brunetti 9, \\ 00186 Rome, Italy. E-mail: n.tocci@iai.it
}

Received: March 12, 2013 Accepted: July 3, 2013 Online Published: July 5, 2013

doi:10.5539/res.v5n3p28

URL: http://dx.doi.org/10.5539/res.v5n3p28

\begin{abstract}
The European Union established in order to bring about peace on the continent has instinctively considered conflict resolution a cardinal objective of its fledging foreign policy. Specifically, it has aimed at reconciling societies and transforming conflict, above simply managing crises and inducing settlements. In view of this, the EU has considered civil society as a key actor in conflict settings. This article seeks to unpack how the EU can engage with civil society actors in conflict areas as well as to provide an analytical framework to understand the EU's impact on conflict through its engagement with civil society. To do so, the article posits three hypotheses: the liberal peace, the disembedded civil society and the Gramscian hypotheses. Rather than addressing which and to what extent these hypotheses apply in the abstract, this article presents a number of empirical examples drawn from the EU's engagement with civil society organizations in several neighbourhood conflicts in order to illustrate their relevance for analysis.
\end{abstract}

Keywords: EU operations, conflict transformation, civil society

\section{Introduction}

The European Union (EU), itself historically regarded as a peace project, has considered conflict resolution a cardinal objective of its fledging foreign policy. More specifically, the EU, in its approach to conflict, has prioritized conflict transformation above conflict management and settlement. The EU is prone to viewing and intervening in conflicts in a bottom-up and structural manner, and many of its policy instruments influence the conditions and incentives playing out at the mid or micro levels of conflict. This is particularly true of EU interactions with neighbouring countries. Many experts consider civil society a key element in any conflict transformation and peace-building strategy. Recognizing this reality particularly in its own neighbourhood, the EU has increasingly appreciated the value of working with local civil society actors.

With these premises in mind, this article seeks to unpack how the EU can engage with civil society actors in conflict areas as well as to provide an analytical framework to understand the EU's impact on conflict through its engagement with civil society. Recognizing that engagement with civil society is an important element in the EU's strategy does not necessarily imply that any such effort will work towards conflict transformation. Not only are civil society organizations (CSOs) extremely varied, so too are their respective impacts on conflict, contributing at times to transformation, at other times to escalation, and at still other times to the status quo., By influencing their nature as well as the political opportunity structure in which they operate, EU engagement with CSOs can affect the overall impact and effectiveness of civil society action in conflicts. It is precisely by engaging with some CSOs rather than others, and/or engaging them through a variety of instruments such as funding, training and dialogue, that the EU can have a variety of impacts on conflicts.

In order to explore the EU's impact on conflict through its engagement with civil society organizations, this article posits three hypotheses, adapted from the original societal pyramid set forth by Lederach (1997). The first hypothesis proposes that the EU's goal in its civil society engagement strategy is to secure a liberal peace. Under this hypothesis, the EU augments its peace strategy targeted at the top levels of society through direct engagement with the mid-levels and, to a lesser extent, the grassroots. In view of the interconnections between top, mid, and grassroots levels, the EU enhances the overall impact of its conflict transformation policies. 
This ideal is not always met. Specifically, one can posit two further hypotheses in which the EU's engagement with civil society has a distorted and distortionary impact on conflict. Under the second hypothesis, or disembedded civil society critique, the EU (over)engages with civil society, altering its very essence in a manner that renders such efforts disconnected and disembedded from the grassroots. In doing so, the EU not only fails to promote genuine civil society development, but also works against its own objective of pursuing peace strategies that have a transformative impact on the ground. Finally, the Gramscian critique, or third hypothesis, posits that the EU (under)engages with the top levels of society. In doing so, the Union does little to alter the overall political opportunity structure in which civil society operates, again doing little to enhance the positive transformative impacts that CSOs can have in conflict contexts.

Rather than addressing which and to what extent these hypotheses apply in the abstract, this article presents a number of empirical examples drawn from the EU's engagement with civil society organizations in several neighbourhood conflicts in order to illustrate their relevance for analysis. The examples are drawn from conflicts both to the south-Israel-Palestine, Morocco-Western Sahara and to the east-Moldova-Transnistria, Georgia-Abkhazia and Armenia-Azerbaijan-Nagorno Karabakh (Note 1).

\section{The European Union and Conflict Transformation}

The Treaty on European Union explicitly states that the EU's aim is to promote peace (Article 3(1)) and that its role in the world should reflect the principles that inspired its creation, development and enlargement (Article 21(1), first subparagraph). The Treaty identifies the preservation of peace, the prevention of conflict and the strengthening of international security as among the Union's core foreign policy priorities (Article 21(2)(c)). More interestingly, the EU's conception of peace, elaborated since the 1990s, has been broad, long-term and organic, and has included the principles of democracy, human rights, the rule of law, international law, good governance and economic development (European Commission, 2001). This conception is tied to that of peacebuilding, which is embedded within the tradition of the "liberal peace" and can be traced back to former UN Secretary General Boutros Ghali's 1992 Agenda for Peace. In other words, as the EU emerged as a foreign policy actor engaged in conflict resolution in the 1990s, it espoused and elaborated the goal of peacebuilding. That aim aligned well both with the EU's own nature and ethos as well as with the approach developed by the United Nations in those years.

Its public pronouncements clearly suggest the EU is intent on promoting conflict transformation rather than conflict management and settlement. Although with development of the Common Security and Defence Policy (CSDP), the EU has deployed a number of civilian and military missions in conflicts worldwide, these have been typically aimed at medium-to-long term goals such as border monitoring and security and judicial sector reform. In other words, the EU is not simply interested in pursuing crisis and conflict management through the maintenance of ceasefires and negotiation of political settlements. It rejects the idea that violent conflict is endemic to human nature and espouses the view that conflict resolution and transformation is possible through the search for mutually beneficial solutions that allow for the satisfaction of all parties' basic human needs (Burton 1990). Further, the EU views as critical "indicators" of conflict prevention and resolution such elements as human and minority rights, democracy, state legitimacy, dispute resolution mechanisms, the rule of law, social solidarity, sustainable development and a flourishing civil society (Kronenberger \& Wouters, 2005). This suggests that the Union aims at transforming the structural features of violent conflict, eradicating what Galtung $(1969,1994)$ has defined as the seeds of structural violence: social injustice, unequal development and discrimination. While theoretically distinct, the EU's approach also fits what Richmond (2005b) conceptually and more broadly has dubbed third-generation "peace-building approaches", which cover the wider economic, political and social make-up of countries before, during and after the end of violent conflict.

Beyond foreign policy objectives, the EU has also developed a variety of policy instruments that are particularly well-suited to pursuing conflict resolution and peace-building. Alongside the sphere of the Common Foreign and Security Policy (CFSP) and the CSDP, the Union promotes conflict transformation principally through its "constructive engagement" with conflict parties (European Commission, 2001: 8-9). By constructive engagement, EU actors mean the deployment of a wide variety of measures of cooperation, which are normally specified in contractual agreements with third countries. These ties take different forms, providing for different degrees of integration in, and cooperation with, the EU. They range from the accession process, aiming at full membership of a candidate country, to looser forms of association, which envisage measures of economic, political and social cooperation with EU structures, to trade and development agreements with African-Caribbean and Pacific countries. These weaker forms of association are also "contractual" in nature. Rather than a Treaty of Accession, as in the case of the membership process, they foresee Association Agreements, Partnership and Cooperation Agreements, Stabilization and Association Agreements, etc. Beyond 
the goal of achieving varying degrees of cooperation with the EU, these contractual relationships aim at fostering long-term structural change, including conflict transformation, within and between third countries.

The promotion of structural and sustainable peace has been ranked above all other aims in the EU neighbourhood. This was made clear in the 2003 Security Strategy, updated in 2008, which argued that the Union's task is to 'make a particular contribution to stability and good governance in our immediate neighbourhood (and) to promote a ring of well governed countries to the East of the EU and on the borders of the Mediterranean with whom we can enjoy cooperative relations' (European Council, 2003). It was reiterated in the Treaty on European Union, which states that the Union 'shall develop a special relationship with neighbouring countries, aiming to establish an area of prosperity and good neighbourliness, founded on the values of the Union' (Article 8(1)). Most tellingly, the documents establishing the European Neighbourhood Policy (ENP) voice the Union's aspiration to contribute to the solution of regional conflicts (European Commission, 2004: 6). The commitment was reasserted in the review of the ENP in 2011 (European External Action Service, 2011: 5).

In particular, the ENP, building upon existing contractual ties with neighbouring countries (e.g., the Association Agreements with the southern Mediterranean countries or the Partnership and Cooperation Agreements with the former Soviet countries), promises to enhance the depth and breadth of EU involvement in neighbourhood conflicts. Not only does the ENP consider conflict resolution as one of its key priorities, but in its Communication, the European Commission (2006a) argues that these conflicts 'are not only our neighbours' problems. They risk producing major spillovers for the EU, such as illegal immigration, unreliable energy supplies, environmental degradation and terrorism'. In another Communication, the European Commission (2007: 6) adds that the Union has 'a direct interest in working with partners to promote their [conflict] resolution, because they [conflicts] undermine EU efforts to promote political reform and economic development in the neighbourhood and because they could affect the EU's own security'. Furthermore, the manner in which the ENP is structured, making use of detailed Action Plans foreseeing long lists of priorities spanning across all policy areas, increases the scope for the EU's bottom-up and long-term involvement in conflict transformation. As stated by the European Commission (2007: 6), 'the deployment of all available tools, whether first, second or third pillar, would increase EU influence and avoid the limitations of short-term crisis management'.

\section{Conflict Transformation and Civil Society}

Within the tradition of conflict transformation and peacebuilding, the role of civil society is of the essence (Lederach 1997, Rupesinghe 1995). Civil society organizations (CSOs) are, on the one hand, pivotal in providing necessary support for peace, ensuring that any agreement negotiated by political leaders is ultimately accepted and implemented on the ground (Miall, Ramsbotham, \& Woodhouse, 1999). On the other hand, civil society organizations can provide the necessary push for peaceful social change, especially when the top levels are unwilling or unable to budge on the fundamental issues of a conflict.

This is not to say that civil society is always and necessarily a force for good. Insofar as civil society is a reflection of society at large, in contexts of violent conflict and divided societies, "uncivil society" inevitably exists, and at times thrives. It can contribute to polarization within and among communities, reinforce horizontal inequalities and legitimize violence in the name of nationalism, exclusionary ideologies and at times even democracy, human rights and self-determination (Barnes, 2005). In other words, civil society is both a potential agent for change and a reflection of the conflict structure. It can both promote conflict transformation and peacebuilding, but also "fuel" or "hold" the conflict, exacerbating or prolonging the status quo (Marchetti \& Tocci, 2009). By operating within a structure of conflict, often marked by state failure, authoritarianism, poverty and insecurity, civil society can be an actor in conflict escalation, encouraging nationalism, ethnocentrism and violence (Paffenholz \& Spurk, 2006). Yet even in these cases, civil society remains a force with which to reckon.

Precisely how and why does civil society contribute to conflict escalation as well as transformation? Civil society, while being distinct from the state, the family and the market, acts as the social glue between these three domains, thus fulfilling an essentially political function in society. In other words, civil society is distinct from, while interacting with, politics and policy (Chazan, 1992: 281). As analysed by Lederach (1997) and reproduced in Figure 1, civil society is active at both mid and grassroots levels of society. At mid-level, there are elite civil society actors, including universities and research centres, professional NGOs, unions and professional associations, local media groups and artists, as well as overtly "uncivil society" groups such as organized crime networks. Smaller NGOs and networks such as community, women's, student and faith-based groups, social movements and activists, combatant groups and supporting institutions, cooperatives, self-help organizations and charities populate the grassroots level. 
Most importantly, civil society links the three stylized levels of society in Lederach's pyramid. On the one hand, mid-level CSOs are closely tied to top-level policy-making through their interactions with parliaments, executives, big businesses, foundations and major media holdings. Through their advocacy, policy research, and negotiation support activities, mid-level CSOs can both ease conflict settlement and press the top levels to modify the structural features of governance that gave rise to conflict in the first place. These mid-level actors build personal and professional relations with the top levels, and play a pivotal function as a result of their unofficial nature. Compared to the top level, mid-level CSOs in fact normally enjoy more political independence, and thus can exercise more creativity and flexibility, as well as enjoy a greater ability to operate beyond the limelight of the media. This allows them to act as critical norm entrepreneurs in conflict transformation (Wallace \& Josselin, 2001). They also have better access to, and dialogue with, diverse sectors of society, being able to talk to different parties without losing credibility, and generally exhibit a greater inclination to work on long-term and structural issues, rather than on short-term ones determined by the current political agenda.

On the other hand, mid-level actors are organically linked to grassroots CSOs, which are the principal agents in the cultivation of "peace constituencies" in society writ large (Lederach, 1997). They do this by mobilizing the public to tackle and react to the underlying conditions of structural or open violence through education, training, capacity building and awareness-raising. Indeed, many social movements are made up of networks of like-minded NGOs operating at the grassroots and mid levels. Mid-level and grassroots CSOs also foster conflict transformation by encouraging societal reconciliation, through inter-communal dialogue, peace commissions, and by promoting functional cooperation and communication across communities. Finally, CSOs can reach out to the wider public through service delivery, whether of a material (e.g., relief and rehabilitation) or psychological (e.g., post-war trauma therapy) nature. Civil society interactions with the public are of the essence in ensuring that the voice of the people is not drowned out in the evolution of both conflict and peace.

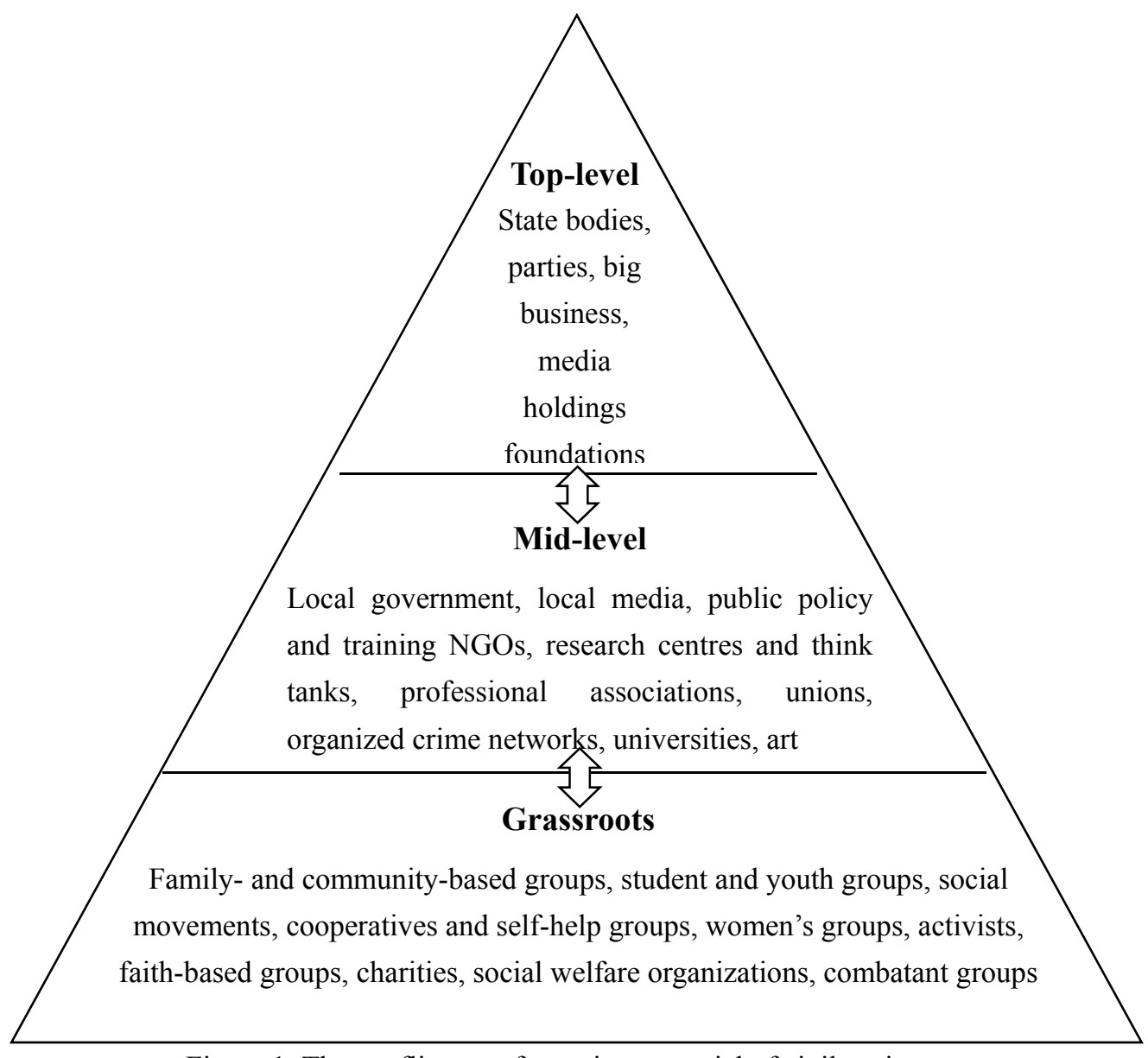

Figure 1. The conflict transformation potential of civil society

Source: Lederach (1997) 


\section{The EU, Conflict Transformation and Civil Society: Methods of Engagement}

As noted above, the EU has acknowledged the importance of engaging with civil society in order to enhance the effectiveness of its foreign policy in general and its peace strategies in particular. The EU views civil society both as an aim to be promoted in and of itself and as a means through which the Union can pursue objectives such as the promotion of peace and the protection of human rights more effectively (Dudouet and Clark 2009).

In particular, the EU increasingly values engaging with local civil society entities in conflict contexts, particularly in the neighbourhood (European Commission, 2006a). These CSOs may often look rather different from international NGOs working on conflict, and may well be non-voluntary in nature, less organized, less professional and with fewer human and financial resources than their international counterparts. Yet whether formally organized or informal associations or non-voluntary groupings, local civil society typically has a significant stake in both conflict and conflict transformation and nuanced understanding and legitimacy as it works to address it (Bell \& Carens, 2004). Rather than acting as an external bystander, civil society organizations are first-hand actors in conflict, and as such represent a necessary, albeit insufficient, actor in promoting peace. Local CSOs can act as the seed for group formation, mobilization, communication and empowerment. These steps are necessary to induce peaceful social change (Varshney, 2001), but may also create the necessary "opportunity” for conflict escalation (Murshed \& Tadjoeddin, 2008).

More specifically, the ENP views local civil society entities as key actors in the neighbourhood, being part of the democratic governance of the EU and of nearby nations, providing valuable monitoring and policy implementation functions as well as contributing advice and expertise to EU institutions and neighbourhood states alike. Alongside global EU policy instruments in support of civil society, such as the Instrument for Stability (IfS) and the European Instrument for Democracy and Human Rights (EIDHR), and the newly minted European Endowment for Democracy, the EU, via its ENP, has developed specific initiatives to support civil society in the neighbourhood. For example, the Union, in the context of the ENP has established platforms for dialogue with neighbourhood civil society organizations (European Commission, 2006a), targeting in particular CSOs working on democratization, human rights, freedom of expression, women's rights, education, environment and research.

The EU has engaged with neighbourhood civil society actors through three principal methods: dialogue, training and funding.

EU institutions engage in dialogue with CSOs by publicly expressing appreciation/condemnation for particular organizations or entities, attending their activities, and facilitating access to contacts and information exchanges among and between those targeted and international actors. The underlying aim of these different forms of dialogue is to gain a deeper understanding of specific conflicts, to socialize CSOs into adopting different positions or pursuing alternate activities, and to raise the morale and status of particular civil society entities. Dialogue occurs through private meetings between CSOs and EU actors. EU institutions can also provide safe venues for CSOs to meet in order to exchange skills, experiences and information. Finally, EU institutions can organize wider public meetings in which CSO representatives are invited to Brussels for information sharing and discussions with Union officials. The annual EU-NGO (Nongovernmental Organization) Human Rights Forum is an institutionalized opportunity for EU consultation with civil society organizations. Likewise, since the late 1990s, the European Parliament and Commission have established regular contact with civil society actors through the Human Rights Contact Group, the Civil Society Contact Group, the Common Foreign and Security Policy Contact Group and the Arms Transfer Contact Group. Furthermore the European Peace-building Liason Office (EPLO), a sub-group of the European Platform of NGOs, established an office in Brussels in 2002 to improve civil society access to EU institutions and policy-makers active in the field of conflict resolution. The EU has focused primarily on European CSOs. The Contact groups with the European Parliament include less than a dozen large European CSOs, while the EPLO includes 23 national or transnational European CSOs and networks.

EU actors also engage with civil society entities through training, for instance by providing scholarships and technical material and training courses to CSO representatives in fields such as communication (e.g., political debate, public relations and advocacy), substantive issues such as international, human rights and EU law, as well as organizational and financial capacity building and recruiting supporters and members. In some cases, training and funding are closely linked, such as the courses offered by EU delegations in some third countries to acquaint CSOs with the necessary procedures and techniques to apply for EU funds. Training can also happen in the reverse direction. Part of the mandate of the EU's IfS, for example, is to support CSOs to provide EU institutions with early warning and conflict information and expertise (Duke \& Courtier, 2010). 
EU engagement with CSOs can also take the form of financial support, including funding to organizations or to specific programmes and projects. Within conflict contexts, several financial instruments are available for precisely this purpose. The IfS is a key example and within it, the Peacebuilding Partnership, which focuses, inter alia, on civil society capacity building, Track II diplomacy and the early warning expertise of CSOs. In addition, the Commission's Research Framework Programmes includes specific actions aimed at CSOs, and funds for civil society are available under the European Neighbourhood and Partnership Instrument (ENPI) and the Instrument for Pre-accession (IPA) as well the EIDHR. Funds allocated within contractual relationships, such as the ENPI or the IPA, are primarily channeled through the intermediation of official institutions in third countries, and only through the latter do they reach civil society. In view of the limits of this approach, the EIDHR and, more recently, the IfS (and in future the European Endowment for Democracy) are of particular relevance since each mechanism bypasses the state. Through them, the EU aims to promote human rights and democracy in the former case and crisis management and peacebuilding in the latter.

\section{The EU's Impact on Conflict Transformation in the Neighbourhood through Engagement with Civil Society: Three Hypotheses}

The three principal EU methods of engagement with civil society entities—dialogue, training and funding — can affect their role(s) in conflicts in two ways. The Union can influence the structural features of conflict, thus shaping the political opportunity structure in which civil society operates. In this way it can affect the effectiveness of civil society organization actions, and in particular two of the critical determinants of such efforts: intra-civil society relations, and relations between CSOs and the state (Paffenholz \& Spurk 2006; Paffenholz 2009). Implementation of ENP Action Plans agreed bilaterally with individual neighbourhood countries could, by shaping the policies and institutional features of conflict nations, influence the overall environment in which civil society operates, facilitating or hindering both CSO interactions, and their relationship and access to the state. By covering a wide range of sectors such as institutions, infrastructure, health, education, trade and investment, Action Plan implementation could thus play a role in shaping the overall environment in which CSOs operate, increasing or reducing the effectiveness of their conflict-related actions.

The ENP can also affect the civil society dimension of conflict by influencing the role of CSOs as agents in conflict and conflict transformation. The EU has recognized the need to strengthen the civil society dimension of the ENP since 2006. Accordingly, it has sought to enhance the quality and status of CSOs in the neighbourhood through exchanges between CSOs in the EU and the neighbourhood in the economic, social and cultural fields, and by making use of the resources available under the ENPI. The European Commission (2006a and 2006b) has also openly suggested enhancing civil society participation in the ENP by encouraging neighbourhood governments to promote civil society involvement in governance. To this end, the Commission organized an ENP conference in September 2007 that brought governmental and civil society actors from the EU and neighbourhood countries together for the first time (European Commission, 2007: 11). In other words, the ENP aims at enhancing the quality and status of local civil society in the neighbourhood through training, exchange and funding and by seeking to develop the domestic political role of CSOs. Financial instruments such as the EIDHR, the IfS and the European Endowment for Democracy (EED) are (and will be in the case of the EED) deployed in support of this goal.

Despite this evidence of the Union's general will to enhance its peacebuilding role in the neighbourhood through civil society, two critical questions remain. First, with which CSOs does the EU engage in the neighbourhood? As discussed above, civil society can fuel conflict as well as promote peace. Do EU officials correctly identify fuelling actors and activities? If so, do they and should they engage with, ignore or seek to weaken those CSOs, and only interact with peacebuilding ones? Second, does the ENP succeed in increasing the effectiveness of peacebuilding civil society activities, or does it instead inadvertently weaken the impact of such efforts?

I offer three hypotheses to address these two fundamental questions. These three propositions are by no means mutually exclusive, and it may well be that features of all three co-exist in the same conflict. In fact, the three hypotheses should be read as ideal (and non-ideal) types, which will rarely be found to apply exclusively in any conflict.

\subsection{Hypothesis 1: The Liberal Peace Paradigm}

A first hypothesis is that the EU contributes to conflict transformation by:

a. strengthening the structure of local civil society by increasing the interconnectedness between mid-level CSOs and top-level actors on the one hand, and mid-level and grassroots actors on the other hand, thus increasing the influence of civil society on conflict 
b. enhancing the agency of peacebuilding CSOs, while weakening or constructively altering the views and actions of fuelling/holding CSOs, primarily by engaging directly with mid-level CSOs (through dialogue or funding) and by indirectly reaching out to peace-oriented grassroots CSOs.

The EU should satisfy two main conditions to fulfil this hypothesis. A minimum threshold objective is that of "doing no harm" (Anderson 1999). The EU thus ensures that its policies, whether aimed at structure or agency, do not have negative distorting effects, such as the delegitimization of peace-building CSOs through excessive co-option or the inadvertent strengthening of conflict fuelling CSOs through openly supporting, ignoring or actively attempting to weaken them. In the neighbourhood, the EU has not had a distorting impact on civil society in Moldova and Transnistria, and to a lesser extent in Georgia, Abkhazia and Armenia. In these cases, as opposed to others and in particular Israel-Palestine, the EU's impact on civil society and, consequently on the conflict, has been marked by two principal features. On the one hand, the EU is active in the conflict country, yet its presence and assistance to civil society has not fundamentally affected or distorted local civil society. On the other hand and related, the EU is perceived rather positively by the conflict parties. The EU may be and is criticized in these countries, yet the nature of the criticism tends to revolve around the fact that the EU's level of engagement is too little rather than too much.

Beyond the minimum "doing no harm" objective is the more ambitious goal of building local capacities for peace by empowering peacebuilding CSOs and weakening or altering the views of fuelling CSOs (Bigdon \& Korf, 2002). As illustrated by Figure 2, the EU can increase the interconnectedness of the three levels of society (point a. above), and it can raise its effectiveness in conflict transformation by interacting with mid-level civil society organizations, which are connected to grassroots entities and the wider public (point b. above). In the eastern neighbourhood, the EU, through its financial support and dialogue with CSOs, has contributed to the development of the civil society sphere. It has tended to fund and support organizations that have had a positive impact on conflict. It has not, however, boycotted altogether organizations that have furthered solutions contrary to its objectives. On the contrary, both in Transnistria and in Abkhazia, the EU has engaged in dialogue with and has supported financially organizations which promote secession, a goal contrary to the Union's own vision. In particular, the EU has played an important role in empowering NGOs in Abkhazia, yet in a manner that has allowed them to keep their essentially grassroots character and to enjoy close ties with the authorities, and which has not prevented them from openly criticizing the EU's role in the region. In Moldova and Transnistria, the Union has sought to strengthen the capacity of CSOs both through funding and by participating in their activities. The EU has opened a channel of communication with the region's authorities via the EU appointed Special Representatives to the South Caucasus and Moldova and by means of Commission delegations in Tbilisi, Baku, Yerevan and Chisinau. These offices have given Union EU actors greater knowledge and awareness of the local civil society scene in the area.

This said, the EU has generally supported civil society organizations and activities that have had only an indirect bearing on the conflict in this region. With the exception of its support for the creation of a network of CSOs dealing with conflict issues in the framework of the Black Sea Synergy, or projects funded in the context of the IfS, the EU has generally supported organizations and activities, in the context of the ENP, the Eastern Partnership as well as funding mechanisms such as the EIDHR, which have not specifically tackled conflict issues. Hence, it has pushed for the involvement of CSOs in the formulation and implementation of the ENP Action Plans, bolstering the monitoring functions of these organizations as well as their standing vis-à-vis both the state and society. In Armenia in particular, the EU's engagement with CSOs in the context of the ENP has expanded the political space for civil society organizations' interactions with the government. In other words, particularly in some of the post-Soviet cases, the liberal peace paradigm hypothesis partly resonates, yet does so within the broader dynamics of EU support for democracy and good governance rather than through the EU's specific peacebuilding ambitions alone.

\subsection{Hypothesis 2: The Disembedded Civil Society Critique}

Under a second hypothesis, EU engagement with local civil society is detrimental to conflict transformation. This is not simply because the Union officials misidentify local CSOs, thus inadvertently strengthening and/or weakening CSOs. It is rather because the very fact of engaging with local civil society alters its character and effectiveness in a manner detrimental to peace.

This can take place in two ways. First, EU interaction and engagement with local civil society entities can lead to an apparent "depoliticization" of local civil society (Fischer, 1997), rendering mid-level CSOs technical instruments at the service of the top levels in both the domestic and the international context. This in turn may lead to a proliferation of CSO activities focussed on the symptoms of conflict, to the detriment of peacebuilding 
activities. This can take the form, for example, of EU engagement and support for liberal, technical, professional service-based and urban NGOs to the detriment of more overtly political CSOs, such as trade unions, social movements, religious charities or community-based organizations operating in more local and rural contexts (Belloni, 2001; Chandler, 2006). EU (and other external) funding and support for civil society in conflict may in fact lead to an "explosion" of the NGO sector, also dubbed "non-grassroots organizations", briefcase NGOs (BRINGOs), mafia NGOs (MANGOs), criminal NGOs (CRINGOs), government-owned NGOs (GONGOs), commercial NGOs (CONGOs) and my-own NGOs (MONGOs) (Reimann, 2005: 42). Driven by external funds, these organizations become veritable businesses and may increase corruption in the civil society domain as well as inequality. They may even create stakeholders with an interest in the continuation of conflict. In this scenario, smaller or more political organizations are either directly shunned by the EU or fail to meet the necessary technical/bureaucratic requirements to be allocated funds. The upshot of this situation is that the potential for the constructive mobilization and politicization of society is reduced, thereby diminishing the prospects of grassroots actors altering the structural conditions of violent conflict.

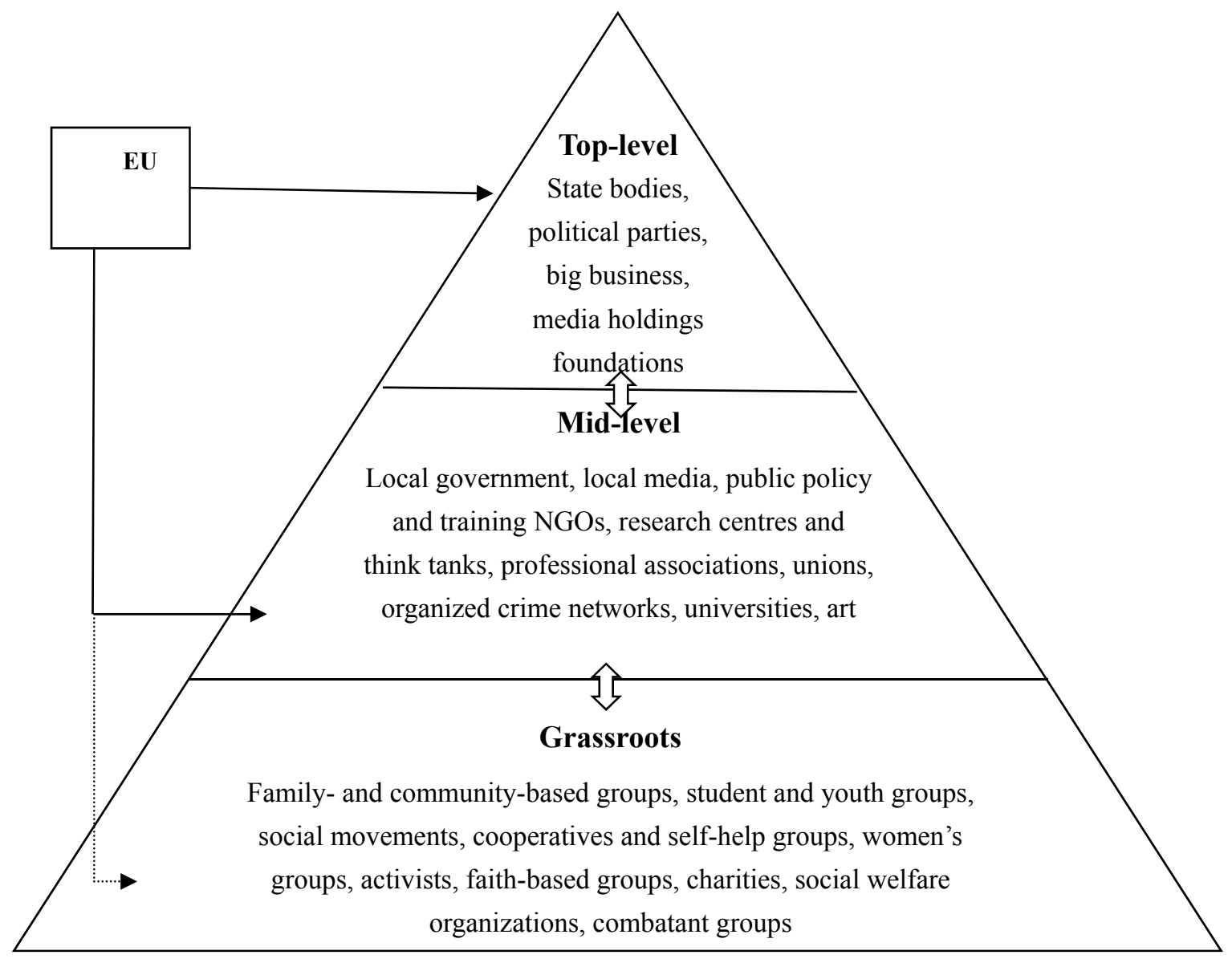

Figure 2. The liberal peace paradigm

Source: adapted from Lederach (1997)

Second, EU or external engagement more generally with civil society entities can excessively "politicize" and co-opt them, transforming local CSOs into representatives for external policies, priorities and proposed solutions, which may be alien to the needs and desires of the conflict parties themselves (Ferguson, 1990; Chandler, 1998). As Richmond (2005a: 26) has observed, in this scenario, CSOs would act 'as thinly veiled fronts for powerful state interests in that they act as a front for the insertion of realist state interests in a disguised form'. Civil society would thus become driven more by the top-down supply of external funds than by the bottom-up demands of societal needs. In an attempt to justify or legitimize EU policies in conflict contexts, civil society actors would delegitimize themselves, to the point of being viewed as "traitors" in the eyes of grassroots actors and the wider public. The mere fact of being funded by an external actor such as the EU could also create the perception in the public's mind that a CSO is acting on behalf of foreign rather than domestic interests. 
In other words, under this second hypothesis, EU policies in conflict contexts would not be strengthened by engagement with local civil society. The reverse would instead be true, whereby the Union's intervention fundamentally shapes and alters the nature of local civil society into a dependent functional substitute within the liberal paradigm of its foreign policy, detaching and delegitimizing it in the eyes of the affected nation, territory or public (Chandler, 2001). In doing so, a limited and distorted form of civil society would emerge, while existing local capacity would be diminished or destroyed (Richmond, 2005a). Civil society would lose its autonomy and become accountable to EU donors rather than to domestic constituencies. It would respond to the Union's political priorities as well as to its tendency to focus on short-term, outcome-driven and quantifiable projects, which may be far removed from the long-term, dynamic, process-driven and multidimensional needs of peacebuilding (Vukosavljevic, 2007). As a result, local civil society involved in peacebuilding would become at best ineffective or at worst could switch into holding or fuelling conflict. Nowhere is this more evident than in EU policies in Palestine (and in the West Bank in particular). The magnitude of EU funds to the West Bank, alongside the Union's skewed focus on some CSOs (i.e., those aimed at alleviating the costs of conflict through humanitarian relief or promoting "contact" between Israelis and Palestinians as an end in itself rather than as a means to induce a cognitive re-articulation of the conflict) at the expense of others (CSOs within the Palestinian diaspora, grassroots entities, Islamic groups or CSOs viewed as too critical of the State of Israel or the Palestinian National Authority) have fostered the growth of a disembedded civil society and the acceleration of the de-democratization of Palestine. As highlighted in Figure 3, the EU, by interacting with top and mid-level actors, has thereby distorted the make-up of civil society, contributing to the detachment of mid-level CSOs from the grassroots and the wider public.
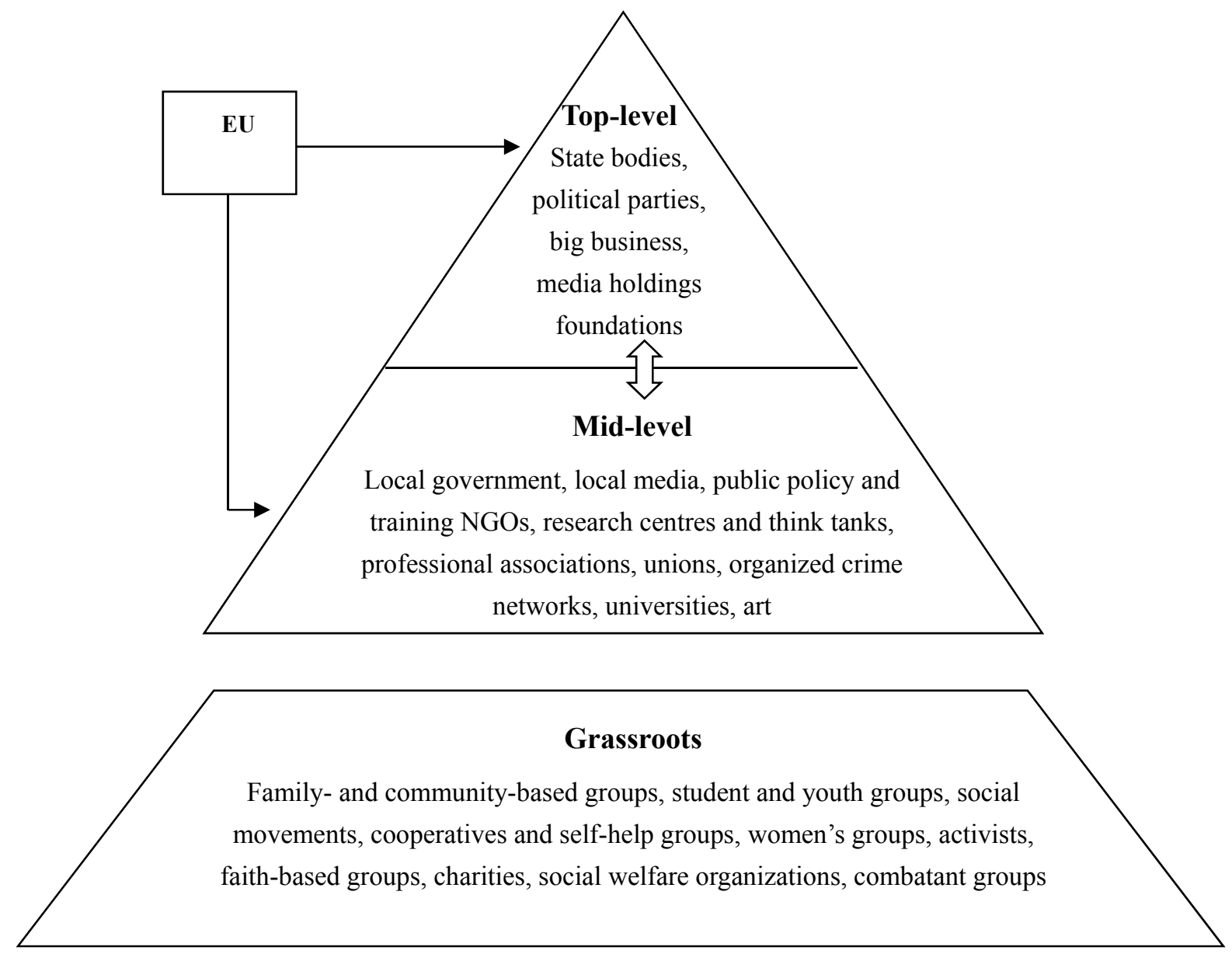

Figure 3. The disembedded civil society critique

Source: adapted from Lederach (1997) 


\subsection{Hypothesis 3: The Gramscian Critique}

A third and final hypothesis assumes that conflict is driven also, if not predominantly, by state-based actors, who in turn, are inextricably tied to the civil and political societies domain in a Gramscian fashion (Gramsci, 1971: 238). In this view, civil society cannot be viewed as an actor in conflict or conflict resolution in isolation. It is rather the role of civil society in interaction with the state that determines civic potential to transform conflict. Equally important is the interaction between the state and civil society in terms of the space the state leaves open to civic engagement, independently and in interaction with its various institutions. More broadly, without a conducive context achieved through institutional and political change, the scope for civil society impact is limited (Fagan, 2010). If such space is limited or non-existent (i.e., in the authoritarian and illiberal contexts often found in conflict situations), EU engagement with civil society is unlikely by itself to have a visible positive impact on conflict. In other words, unless the Union exerts effective pressure on state actors to engage in democratic reform and alters the structure in which civil society operates, its efforts are unlikely to induce conflict transformation. Likewise, if the EU engages with state actors by supporting or failing to persuade neighbourhood states to alter their structural political deficiencies, then its support, engagement and financing of civil society cannot improve the effectiveness of its conflict transformation policies. This scenario is highlighted in Figure 4, which shows the detachment of the top levels of society from mid-level and grassroots actors. In this context, EU activities ineffectively influence conflicts by engaging with CSOs, yet failing to engage the top levels effectively so as to bring about structural change.

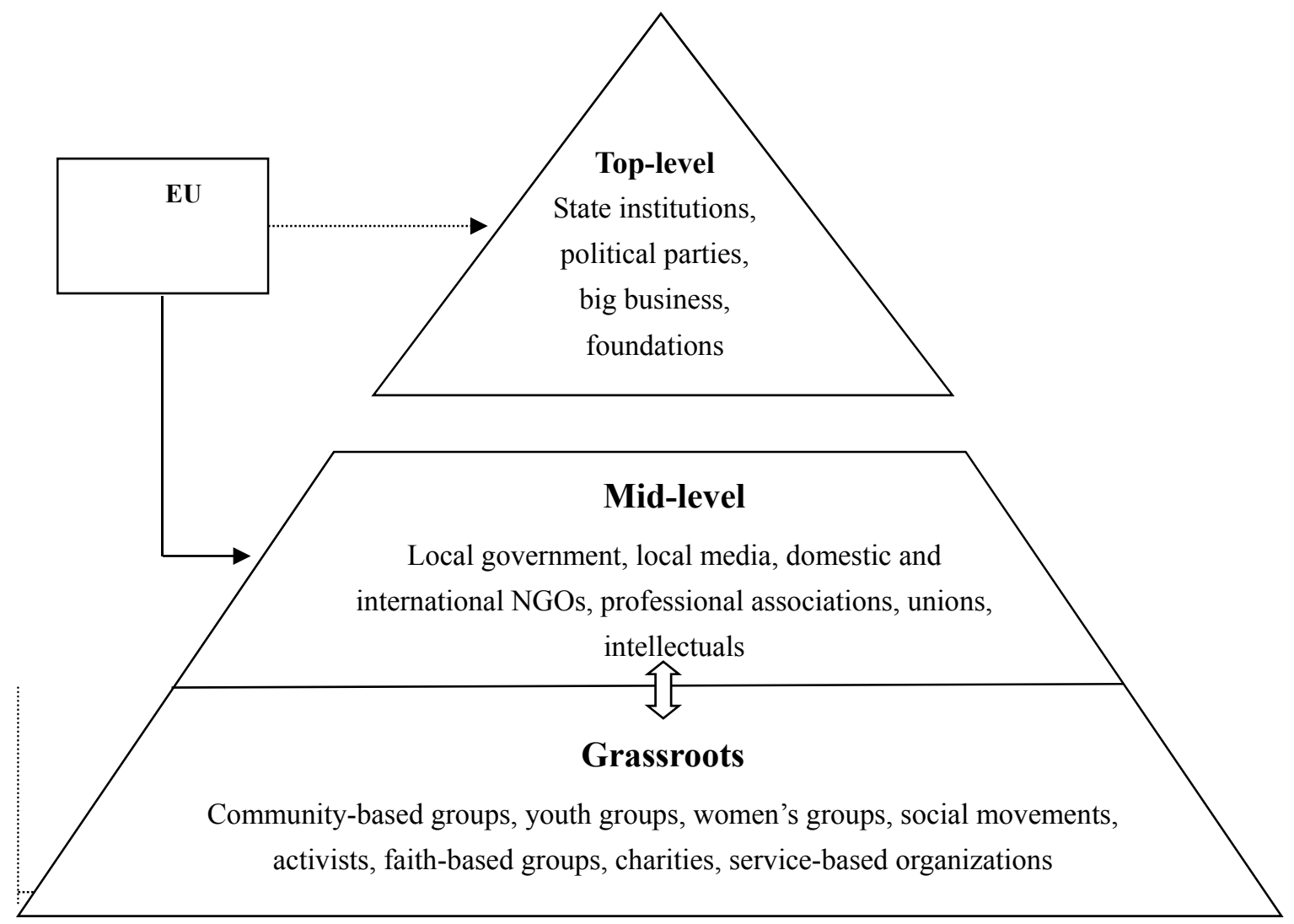

Figure 4. The Gramscian Critique

Source: adapted from Lederach (1997)

Indeed, EU efforts in conflict countries often seem to be marked be a paradox. The Union attaches prime importance to official negotiations. Yet with the exception of the conflict in Moldova-Transnistria, the EU has not defined a specific settlement strategy in any of the regions in which it has worked. In Nagorno-Karabakh, Abkhazia and Western Sahara, for example, the EU has paid lip service to dysfunctional mediation forums-the Minsk Group of the Organization for Security and Cooperation in Europe and the United Nations-without attempting to contribute actively to reviving them. In Israel-Palestine, the Union has been a member of the Quartet (also including the United States, Russia and the United Nations) since 2002, but it has never attempted 
to replace, nor in fact to influence meaningfully, Washington's mediation. In practice, this has meant playing into the status quo and its conflict escalating dynamics. The dissatisfaction inherent in the fact that the EU attributes importance to Track I negotiations, but plays only a passive role in them, has sometimes poisoned its approach to civil society in this conflict. At times indeed, Union engagement with civil society has constituted a surrogate for an active role in mediation. The EU's over-engagement with (a segment of) Palestinian civil society is a case in point. At other times, the absence of a political strategy towards the conflict has meant not engaging with civil society at all, in acquiescence to particular regimes. This is the case with regard to the EU's non-engagement with Saharawi CSOs, Palestinian CSOs in Gaza and more broadly with CSOs with an Islamic identity. To a lesser extent the same can be said of the EU's highly circumscribed approach to CSOs in Nagorno-Karabakh and Azerbaijan. In the first case the EU's excessive caution is due to the non-recognized status of the enclave. In the second instance it is the result of the highly authoritarian nature of the regime and its suspicion of European Union engagement with local civil society entities. Noteworthy in this respect is the fact that the first EU grant for local CSOs in Azerbaijan occurred only in 2008 (in the framework of the EIDHR).

\section{Conclusions}

This article has unpacked analytically the links between three elements: the EU, civil society organizations and conflict. As noted at the outset, the European Union, in view of its very nature, has been prone to viewing conflict and peace comprehensively. Its instinctive philosophy has been to promote peacebuilding over and above narrow objectives of conflict and crisis management. The Union has explicitly recognized the key roles that civil society groups and organizations play in conflict and peace, particularly when the latter is interpreted broadly. This appreciation has become even starker in light of the Arab uprisings in the EU's southern neighbourhood. The EU has acted on this recognition, engaging civil society organizations, particularly at the local level, within conflict countries. This stance, however, does not necessarily mean that the EU has always and necessarily engaged civil society effectively to promote conflict transformation. This article has outlined an analytical framework to make sense of such EU engagement, highlighting through examples drawn from the European neighbourhood, the varied results the Union has achieved by acting through civil society entities in conflict countries.

Civil society groups and organizations alone cannot peacefully transform conflict. Yet, particularly when conflict narratives are deeply embedded and conflict settlement processes deadlocked, such entities can sow the seeds of positive transformation. EU engagement with civil society organizations in societies in conflict is thus necessary. But alone, it is insufficient. In order for the Union to contribute to conflict transformation in its neighbourhood, its engagement with civil society must be part of a multidimensional strategy, aimed at international as well as local actors in conflict, including top, mid and grassroots levels.

\section{References}

Anderson, M. (1999). Do No Harm: How Aid Can Support Peace - Or War. Boulder and London: Lynne Reinner.

Barnes, C. (2005). Civil Society Roles in Working with Conflict and Building Peace. Peace-Dialogue: Cooperative Peace Project. Retrieved January 18, 2009, from $\mathrm{http} / / /$ www.peoplebuildingpeace.org/thestories/print.php?id=68\&typ=refl

Bell, D., \& Carens, J. H. (2004). The Ethical Dilemmas of International Human Rights and Humanitarian NGOs: Reflections on a Dialogue Between Practitioners and Theorists. Human Rights Quarterly, 26(2), 300-329. http://dx.doi.org/10.1353/hrq.2004.0017

Belloni, R. (2001). Civil Society and Peacebuilding in Bosnia and Herzegovina. Journal of Peace Research, 38(2), 163-180. http://dx.doi.org/10.1177/0022343301038002003

Bigdon, C., \& Korf, B. (2002). The Role of Development Aid in Conflict Transformation: Facilitating Empowering Processes and Community Building. Berghof Papers. Berlin: Berghof Research Center for Constructive Conflict Management.

Burton, J. (Ed.). (1990). Conflict: Human Needs Theory. London: Macmillan.

Chandler, D. (1998). Democratization in Bosnia: The Limits of Civil Society Building Strategies. Democratization, 5(4), 1-17. http://dx.doi.org/10.1080/13510349808403585

Chandler, D. G. (2001). The Road to Military Humanitarianism: How the Human Rights NGOs Shaped a New Humanitarian Agenda. Human Rights Quarterly, 23(3), 678-700. http://dx.doi.org/10.1353/hrq.2001.0031

Chandler, D. (2006) (Ed.) Peace Without Politics: Ten Years of Statebuilding in Bosnia, London: Routledge. 
Chazan, N. (1992). Africa's democratic challenge. World Policy Journal, 9(2), 279-307.

Dudouet, V., \& Clark, H. (2009) Nonviolent Civic Action in Support of Human Rights and Democracy, Brussels: European Parliament, DG for External Policies-Policy Department (EXPO/B/DROI/2008/69).

Duke, S., \& Courtier, A. (2010). EU Peacebuilding: Concepts, Players and Instruments'. In S. Blockmans, J. Wouters, \& T. Ruys (Eds.), The EU and Peacebuilding. Leiden: Asser Press. http://dx.doi.org/10.1007/978-90-6704-691-6_2

European Commission. (2001). Communication from the Commission on Conflict Prevention. COM(2001) 211 final, Brussels, 11 April.

European Commission. (2004). European Neighbourhood Policy. Strategy Paper. Communication from the Commission, $\operatorname{COM}(2004) 373$ Final, Brussels, 12 May.

European Commission. (2006a). Communication from the Commission to the Council and the European Parliament on Strengthening the European Neighbourhood Policy. COM (2006), 726 final, Brussels.

European Commission. (2006b). Non-Paper Expanding on the Proposals Contained in the Communication to the European Parliament and the Council on "Strengthening the ENP": Strengthening the Civil Society Dimension of the ENP. Com (2006) 726 Final, Brussels, 4 December.

European Commission. (2007). Communication From The Commission A Strong European Neighbourhood Policy. COM(2007) 774 Final, Brussels, 5 December.

European Council. (2003). A Secure Europe in a Better World. European Security Strategy. Brussels. 12 December. Retrieved May 12, 2008, from http://ue.eu.int/pressdata/EN/reports/78367.pdf

European External Action Service. (2011). A New Response to a Changing Neighbourhood. Joint Communication by the High Representative of The Union For Foreign Affairs And Security Policy and the European Commission. Retrieved from http://ec.europa.eu/world/enp/pdf/com_11_303_en.pdf

Fagan, A. (2010). Europe's Balkan Dilemma: Paths to Civil Society or State-Building? London: I.B. Tauris \& Company.

Ferguson, J. (1990). The Antipolitics Machine, Depoliticisation and Bureaucratic Power in Lesotho. Cambridge: Cambridge University Press.

Fisher, W. F. (1997). Doing Good: The Politics and Antipolitics of NGO Practices. Annual Review of Anthropology, 26, 439-464. http://dx.doi.org/10.1146/annurev.anthro.26.1.439

Galtung, J. (1969). Violence, Peace and Peace Research', Journal of Peace Research, 6(3), 167-192. http://dx.doi.org/10.1177/002234336900600301

Galtung, J. (1994). Human Rights in Another Key. Cambridge: Polity.

Gramsci, A. (1971). In Q. Hoare, \& G. Nowell-Smith, Selections from the Prison Notebooks. London, Lawrence and Wishart.

Kronenberger, V., \& Wouters, J. (Eds.). (2005). The EU and Conflict Prevention: Policy and Legal Aspects. The Hague: Asser Press.

Lederach, J. P. (1997) Building Peace: Sustainable Reconciliation in Divided Societies. Washington, D.C.: United States Institute of Peace.

Marchetti, R., \& Tocci, N. (2009). Conflict society: understanding the role of civil society in conflict. Global Change, Peace and Security, 21(2), 201-217. http://dx.doi.org/10.1080/14781150902872091

Miall, H., Ramsbotham, O., \& Wodhouse, T. (1999). Contemporary Conflict Resolution. Cambridge: Polity.

Murshed, M., \& Tadjoeddin, Z. (2008). Reappraising the Greed and Grievance Explanations for Violent Internal Conflict. Research Working Paper, 2, MICROCON. Retrieved October 9, 2009, from http://www.microconflict.eu/publications/publications.html

Paffenholz, T. (2009). Civil Society and Peacebuilding. CCDP Working Paper (Vol. 4). Geneva: The Centre on Conflict, Development and Peacebuilding.

Paffenholz, T., \& Spurk, C. (2006). Civil Society, Civic Engagement and Peacebuilding. Social Development papers, Conflict Prevention and Reconstruction papers, 36. World Bank: Washington DC.

Reimann, K. D. (2005). Up to No Good? Recent Critics and Critiques of NGOs'. In O. Richmond, \& H. Carey 
(Eds.), Subcontracting Peace. The Challenges of NGO Peacebuilding. Aldershot: Ashgate.

Richmond, O. (2005a). The Dilemmas of Subcontracting the Liberal Peace. In O. Richmond, \& H. Carey (Eds.), Subcontracting Peace. The Challenges of NGO Peacebuilding (pp. 19-35). Aldershot: Ashgate. http://dx.doi.org/10.1057/9780230505070

Richmond, O. (2005b). The Transformation of Peace. New York and London: Palgrave.

Risse, T., Ropp, S. C., \& Sikkink, K. (Eds). (1999). The Power of Human Rights. International Norms and Domestic Change. Cambridge: Cambridge University Press. http://dx.doi.org/10.1017/CBO9780511598777

Rupesinghe, K. (1995) Conflict Transformation. London: St Martins Press.

Tocci, N. (Ed.). (2011). The European Union, Civil Society and Conflict. London: Routledge.

UN Secretary General. (2004). Secretary-General's opening remarks at the Security Council debate on "The role of civil society in post-conflict peacebuilding”. New York, 22 June. Retrieved June 26, 2008, from http://www.un.org/apps/sg/printsgstats.asp?nid=989

Varshney, A. (2001). Ethnic Conflict and Civil Society. World Politics, 53(3), 362-398. http://dx.doi.org/10.1353/wp.2001.0012

Vukosavljevic, N. (2007). Training for Peacebuilding and Conflict Transformation. Experiences of the "Centre for Nonviolent Action". Berghof Papers. Berlin: Berghof Research Center for Constructive Conflict Management.

Wallace, W., \& Josselin, D. (Eds.). (2001). Non-State Actors in World Politics. New York: Palgrave.

\section{Note}

Note1. This article draws on the research results of MICROCON, a three-year Integrated Project financed by the European Commission. The results of this project are published in full in Tocci (2011).

\section{Copyrights}

Copyright for this article is retained by the author(s), with first publication rights granted to the journal.

This is an open-access article distributed under the terms and conditions of the Creative Commons Attribution license (http://creativecommons.org/licenses/by/3.0/). 